\title{
Environmental and climatic changes in central Chilean Patagonia since the Late Glacial (Mallín El Embudo, $44^{\circ} \mathrm{S}$ )
}

\author{
M. E. de Porras ${ }^{1}$, A. Maldonado ${ }^{1,2}$, F. A. Quintana ${ }^{3}$, A. Martel-Cea ${ }^{1,4}$, O. Reyes $^{5}$, and C. Méndez ${ }^{6}$ \\ ${ }^{1}$ Centro de Estudios Avanzados en Zonas Áridas (CEAZA), Raúl Bitran s/n, La Serena, Chile \\ ${ }^{2}$ Universidad Católica del Norte, Larrondo 1281, Coquimbo, Chile \\ ${ }^{3}$ CENAC, Parque Nacional Nahuel Huapi, Fagnano 244, Bariloche, Río Negro, Argentina \\ ${ }^{4}$ Departamento de Biología, Universidad de La Serena, Raúl Bitrán s/n, La Serena, Chile \\ ${ }^{5}$ Centro de Estudios del Hombre Austral, Instituto de la Patagonia, Universidad de Magallanes, Avenida Bulnes 01855, \\ Casilla 113-D, Punta Arenas, Chile \\ ${ }^{6}$ Departamento de Antropología, Facultad de Ciencias Sociales, Universidad de Chile, Ignacio Carrera Pinto 1045, Nuñoa, \\ Santiago, Chile
}

Correspondence to: M. E. de Porras (meugenia.deporras@ceaza.cl)

Received: 15 August 2013 - Published in Clim. Past Discuss.: 17 October 2013

Revised: 7 March 2014 - Accepted: 12 March 2014 - Published: 28 May 2014

\begin{abstract}
Multi-millennial environmental and climatic changes in central Chilean Patagonia (44-49 $\mathrm{S}$ ) during the Last Glacial-Interglacial cycle have been of particular interest as changes in the position and strength of the southern westerlies are the major forcing factor conditioning the environmental dynamics. Recent attempts to reconstruct regional environmental and climatic signals from central Chilean Patagonia reveal some discrepancies and unclear issues among the records. This paper presents the $13 \mathrm{ka}$ pollen

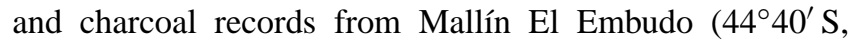
$71^{\circ} 42^{\prime} \mathrm{W}$ ) located in the deciduous Nothofagus forest in the middle Río Cisnes valley. The paper aims to (1) establish the timing and magnitude of local vegetation changes and fire activity since the Late Glacial and (2) integrate these results at the regional scale in order to discuss the discrepancies and depict the environmental and climatic dynamics in central Chilean Patagonia since the Late Glacial. Open landscapes dominated by grasses associated with scattered Nothofagus forest patches dominated the middle Río Cisnes valley between 13 and $11.2 \mathrm{ka}$ suggesting low effective moisture but also indicating that landscape configuration after glacial retreat was still ongoing. At $11.2 \mathrm{ka}$, the sudden development of an open and quite dynamic Nothofagus forest probably associated with the synchronous high fire activity occurred, suggesting a rise in effective moisture associated with dry summers. Since $9.5 \mathrm{ka}$, the record reflects the presence of a
\end{abstract}

closed Nothofagus forest related to higher effective moisture conditions than before combined with moderate dry summers that may have triggered a high frequency of low-magnitude crown fires that did not severely affect the forest. The forest experienced a slight canopy opening after $5.7 \mathrm{ka}$, probably due to slightly drier conditions than before followed by a sudden change to open forest conditions around $4.2 \mathrm{ka}$ associated with fire and volcanic disturbances. Around $2 \mathrm{ka}$, the recovery of a closed Nothofagus forest related to slightly wetter conditions (similar to present) occurred and persisted under highly variable climatic conditions up to $0.1 \mathrm{ka}$ when massive forest burning and logging due to European settlements occurred. Central Chilean Patagonian climatic and environmental changes at millennial-centennial timescales since the Late Glacial were driven by changes in the southern westerlies latitudinal position and/or intensity, but during the late Holocene fire, volcanism and humans arose as forces contributing to environmental dynamics.

\section{Introduction}

Past environmental and climatic variability of Patagonia $\left(40-55^{\circ} \mathrm{S}\right)$ since the Late Glacial has been a major research topic because changes in the position and strength of the southern westerlies (SWs) are the major forcing factor 
conditioning environmental trends. Sensitive-to-precipitation proxies from appropriately located records along Patagonia allow to indirectly trace SW past dynamics since a positive correlation between zonal wind speed and local precipitation exists throughout the Pacific coast and inland areas on the leeward and side of the Andes ( $r=0.8$ to 0.4; Garreaud et al., 2013).

Patagonian records indicate that during the Last Glacial Maximum $(\sim 21 \mathrm{ka}$; thousand calendar years before present $)$, the SW core was shifted equatorward of its modern position, centered on $41^{\circ} \mathrm{S}$ (e.g., Villagrán, 1990; Moreno et al., 1999). Later on, the SW would have shifted southwards to their present position around $14.3 \mathrm{ka}$ and even further southwards around $12.5 \mathrm{ka}$ followed by a weakening after $11 \mathrm{ka}$ (Markgraf et al., 1992). The onset of the mid-Holocene ( $8 \mathrm{ka}$ ) was characterized by an increase in the intensity of the SW, whereas paleo-records after $5 \mathrm{ka}$ reflect a regional, zonal and meridional heterogeneity (Moreno et al., 2010a). Paleoclimate archives from southern South America indicate an increase in westerly wind intensity during the last 2000 years that culminates between 0.4 and $0.05 \mathrm{ka}$ (Moy et al., 2009). A recent hemispheric view of SW dynamics proposed that they have changed in a zonally symmetric manner at multimillennial scale between 14 and $5 \mathrm{ka}$ driven by intra-seasonal insolation changes (Fletcher and Moreno, 2011). However, after $5 \mathrm{ka}$, a breakdown of this symmetry occurred, implying that changes in the strength and latitudinal position of the southern westerlies were modulated at seasonal to interannual timescales by large-scale climate phenomena such as El Niño-Southern Oscillation and/or Southern Annular Mode (Fletcher and Moreno, 2011).

Current understanding of paleoclimatic dynamics from central Chilean Patagonia (44-49 $\mathrm{S}$ ) is scarce, compared to northern and southern Chilean Patagonia. Despite the small number of available paleoecological records, their broad geographical distribution and their extended chronologies have allowed central Chilean Patagonia multi-millennial paleoclimatic dynamics during the Last Glacial-Interglacial cycle to be inferred (de Porras et al., 2012). Nevertheless, there are some issues that need to be addressed in order to achieve a unified regional picture. On one hand, opposite precipitation trends have been proposed for eastern central Chilean Patagonia during the Late Glacial (de Porras et al., 2012; Markgraf et al., 2007; Villa-Martinez et al., 2012). According to Markgraf et al. (2007) and de Porras et al. (2012), grass-shrub steppe development in eastern central Chilean Patagonian sites after Last Glacial Maximum termination indicates dry conditions, whereas Villa-Martínez et al. (2012) inferred the local presence of evergreen forest, which would suggest wetter conditions than present. On the other hand, late Holocene environmental dynamics in central Chilean Patagonia appear highly variable when compared to eastern paleoclimatic records, but whether this variability is climatically driven or related to other forces such as fire, volcanism, and/or human activities remains unclear.
According to these issues, this paper presents the $13 \mathrm{ka}$ pollen and charcoal records from Mallín El Embudo $\left(44^{\circ} 40^{\prime} \mathrm{S}, 71^{\circ} 42^{\prime} \mathrm{W}\right)$ located in the Río Cisnes valley in order to establish the timing and magnitude of changes of the local vegetation and fire regime since the Late Glacial. Besides, local inferences from Mallín El Embudo are then integrated at the regional scale in order to discuss the above-mentioned discrepancies or unclear issues and depict the central Chilean Patagonia paleoenvironmental and climatic dynamics since the Late Glacial.

\section{Modern environmental setting}

The Río Cisnes valley (RCV, $44^{\circ} 40^{\prime} \mathrm{S}$, Fig. 1a) is a westeast-oriented valley that was occupied by a former glacier lobe of the Patagonian ice sheet during the Last Glacial Maximum (LGM) (Glasser et al., 2008) (Fig. 1b). Therefore, RCV landscape has been mainly shaped by glacial erosion presenting an LGM morainic complex in the upper part of the valley, which constitutes the current Chile-Argentina border (Caldenius, 1932; Glasser et al., 2008; Quensel, 1910; Steffen, 1909), a frontal moraine product of a glacial re-advance during the Late Glacial, and several paleo-lake shorelines related to former ice-dammed lakes that flooded the upper and middle RCV after the LGM and during the Late Glacial, respectively (Fig. 1b).

The main climate feature along RCV is the abrupt westto-east precipitation gradient, which is the consequence of the rain shadow effect produced by the forced subsidence of the southern westerlies over the Andes (Fig. 1c). Annual precipitation ranges from $3400 \mathrm{~mm}$ on the west coast (Puerto Cisnes; $44^{\circ} 55^{\prime} \mathrm{S}, 72^{\circ} 70^{\prime} \mathrm{W}$ ) to $450 \mathrm{~mm}$ (Río Cisnes ranch; $44^{\circ} 30^{\prime} \mathrm{S}, 71^{\circ} 24^{\prime} \mathrm{W}$ ) close to the Chile-Argentina border, whereas mean annual temperature ranges between 3.9 and $9{ }^{\circ} \mathrm{C}$ (Fig. 1c) (Luebert and Pliscoff, 2006).

Present-day vegetation physiognomy and composition in the RCV follows the decreasing west-east precipitation gradient (Fig. 1c). Thus, on the west slope of the Andes plant communities range from the coastal evergreen forest of Pilgerodendron uviferum and Astelia pumila, the evergreen forest of Nothofagus betuloides and Desfontainia spinosa, to the deciduous forest of Nothofagus pumilio and Ribes cucullatum (Fig. 1c). On the lee side of the Andes, plant communities include the deciduous forest of Nothofagus pumilio and Berberis illicifolia, the shrubland of $N$. antarctica and Berberis microphylla, whereas the Festuca pallescens grass steppe with Mulinum spinosum is present on the Patagonian plateau (Fig. 1c) (Luebert and Pliscoff, 2006).

Mallín El Embudo ( $44^{\circ} 40^{\prime} \mathrm{S}, 71^{\circ} 42^{\prime} \mathrm{W}$; $686 \mathrm{~m}$ a.s.l.) is a small ( $0.6 \mathrm{ha})$ ombrotrophic fen of Cyperaceae (mallín, hereafter) located in the middle Río Cisnes valley (MRCV) in the Nothofagus pumilio and Berberis illicifolia deciduous forest (Fig. 1b). The arboreal stratum is dominated by Nothofagus pumilio often associated with $N$. betuloides 


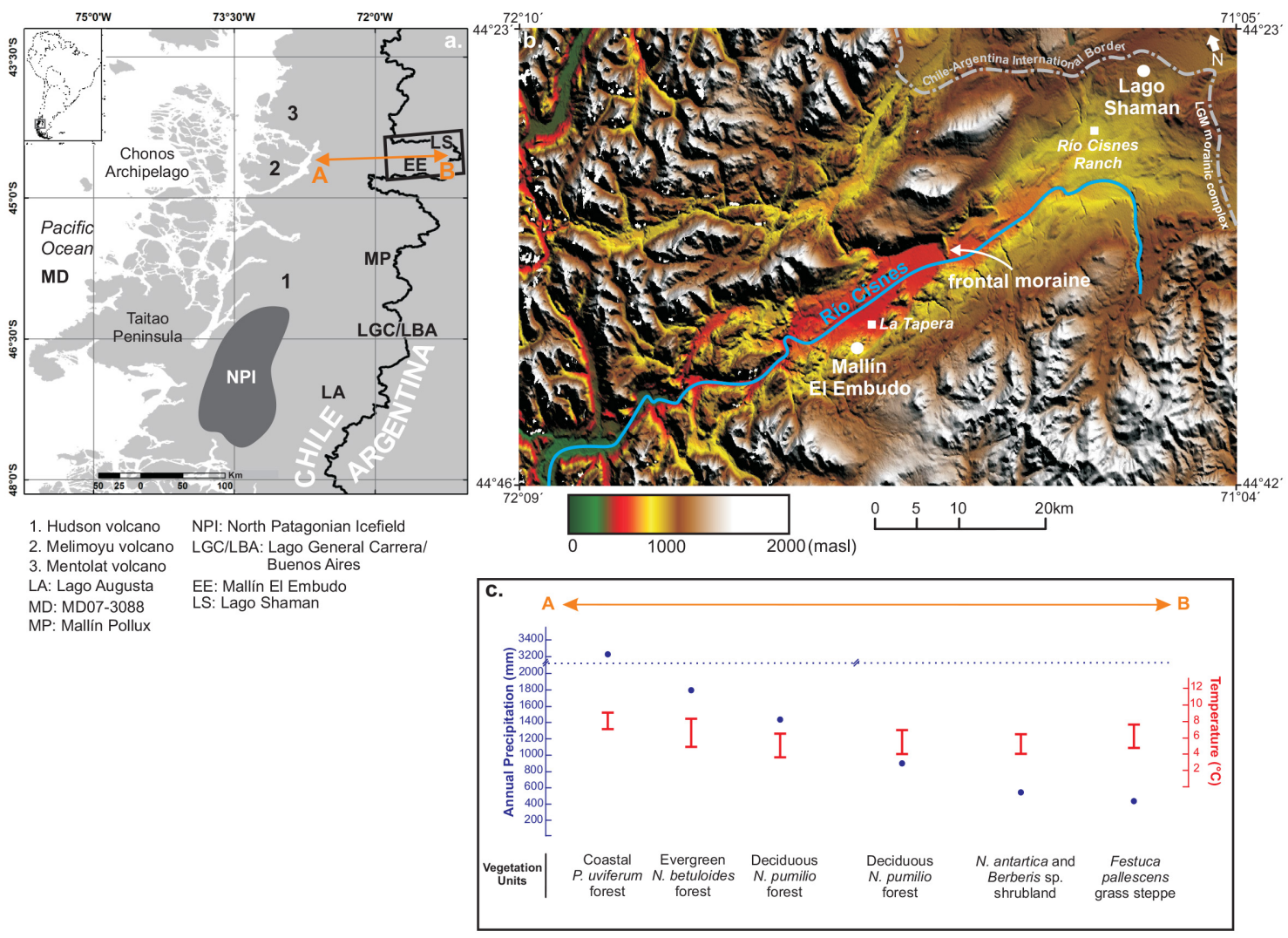

Figure 1. (a) Map showing location of Río Cisnes valley (black square) and sites mentioned in the text; (b) upper and middle Río Cisnes valley digital elevation model (DEM) showing location of Mallín El Embudo and major geomorphological features; (c) annual precipitation, mean annual temperature and major vegetation units along a west-east transect within the Río Cisnes valley (A-B).

and accompanied by shrubs like Berberis illicifolia, Escallonia alpina, Berberis serratodentata, Myoschilos oblonga, Maytenus disticha, herbs including Valeriana lapathifolia, Macrachaenium gracile, Viola reichei, Adenocaulon chilense and Dysopsis glechomoides and ferns (Blechnum pennamarina). The deciduous forest diversity decreases towards the east so that $N$. pumilio associated with Chiliotrichum rosmarinifolium and Poa alopecurus dominates (Luebert and Pliscoff, 2006).

Deciduous Nothofagus pumilio forest dynamics is controlled by medium-to-large-scale disturbances such as fires, volcanism, logging and herbivory (Veblen et al., 1995, 1996).

Fires break the Nothofagus pumilio forest balance between the canopy and the understory, providing higher light conditions and bare soils to be colonized by soil-stored seed plants belonging to the forest and/or other plants from adjacent communities (Vidal and Reif, 2011). Post-fire Nothofagus pumilio deciduous forest regeneration is really slow (20 to 40 years to flourish and fructify) and restricted to a narrow band at the forest margin where conditions are amenable, with adequate seed sources, shelter and proper soil conditions (Kitzberger et al., 2005; Veblen et al., 1996).
Wildfires in forests from central Chilean Patagonia (CCP) mainly occur in summer from January to March when temperatures are warm and fuel conditions are most likely to be dry (CONAF; www.conaf.cl). Even though lightning-ignited fires are rare, Holz and Veblen (2009) recorded numerous lightning-caused scars on CCP rainforests that were associated with charcoal, indicating that wildfire spread to the surrounding vegetation. Wildfire occurrence in CCP rainforests is climate-limited given that fire is not limited by fuel amount in such high biomass environments but strongly associated with reduced spring precipitation resulting in low fuel moisture levels during the summer fire season (Holz and Veblen, 2009). Considering the latter and the level of fire activity curve along a vegetation gradient (very similar to the W-E gradient in CCP) proposed by Whitlock et al. (2010), wildfires in the Nothofagus pumilio deciduous forest that surrounds our study site would also be climate-limited. Moreover, wildfire occurrence in the Nothofagus pumilio deciduous forests might be more frequent than in the rainforests (coastal Pilgerodendron uviferum and evergreen Nothofagus betuloides forest; Fig. 1c). Their eastern distribution along the precipitation gradient (Fig. 1c) would result in dried fuels 
more easily being burned during the summer fire season under lower (spring) precipitation conditions.

The main volcanic disturbance that could affect the deciduous Nothofagus forest from RCV may be pyroclastic deposition (ash fallouts) given its distance $(>100 \mathrm{~km})$ to the closest volcanoes (eg., Hudson, Mentolat, Melimoyu; Fig. 1a). Volcanic disturbances produce forest defoliation, canopy openings and burial of understory plants (Tsuyuzaki, 1995). Therefore, as with fire, volcanic disturbances generate optimal conditions for the establishment and proliferation of fast-growing shade-intolerant plants at the expense of the tree stratum (del Moral and Grishin, 1999; Foster et al., 1998).

Human occupations in the Río Cisnes valley have been recorded since $11.5 \mathrm{ka}$ (Méndez et al., 2009). Archaeological evidence obtained in the upper RCV (El Chueco-1 site) indicates that hunter-gatherers inhabited the grass steppe extensively, though non-permanently, throughout the Holocene (Méndez et al., 2011). Data on stable isotopes support the latter indicating that human beings relied on steppe resources as a staple and thereby spent most of the time in those environments (Méndez et al., 2014). On the other hand, forests were not extensively occupied until $2.8 \mathrm{ka}$ when a series of short human incursions were detected in the middle and lower RCV (Alero Las Quemas and Alero El Toro sites; Méndez and Reyes, 2008). After $2.4 \mathrm{ka}$, no human occupations have been recorded in areas other than the grass steppes, thereby suggesting a retraction to the originally populated environments (Reyes et al., 2009).

European settlement in the RCV occurred at the beginning of the 20th century (1904) when the Río Cisnes Ranch, a sheep breeding farm ( $\sim 50000$ animals $)$, was established (Martinic, 2005). Since then, massive intentional fires and logging were conducted in order to clear the Nothofagus deciduous forest and shrubland and broaden grazing areas. According to historical chronicles, human settlements (around La Tapera village, Fig. 1b) were not established in the MRCV until 1930, so strong human-induced landscape changes were actually late around the Mallín El Embudo area (Martinic, 2005).

\section{Material and methods}

Two sediment cores (EE0110A/B) were recovered from Mallín El Embudo using a modified Livingstone piston corer.

A lithological description, X-radiographs and a preliminary tephra analysis were performed to characterize the stratigraphy of the cores. Subsamples were separated for loss on ignition (LOI), tephra, pollen and macroscopic charcoal analysis. LOI was performed at $1 \mathrm{~cm}$ intervals along the sediment core in $1 \mathrm{~cm}^{3}$ of material to determine organic and inorganic (carbonates and clastic fraction) contents (Begtsson and Enell, 1986; Heiri et al., 2001).

The preliminary tephra analysis performed by C. Stern (University of Colorado) consisted of washing the samples in water to remove organics and clay followed by examination under petrographic microscope to determine glass color and mineral content. Based on this analysis, the tephras were preliminarily assigned to a volcano source and an eruption event. These results need to be confirmed through chemical analysis by inductively coupled plasma mass spectroscopy (ICP-MS) techniques.

The chronology of the Mallín El Embudo record was constrained by nine radiocarbon dates (Table 1) which were calibrated using the CALIB 6.1.0 program (Stuiver et al., 2005). Dates earlier than $9720{ }^{14} \mathrm{C}$ BP years were calibrated with the Southern Hemisphere curve (SHCal04) (McCormac et al., 2004), whereas the three latest dates were calibrated by applying the Northern Hemisphere curve (Reimer et al., 2004).

An age-depth model based on eight of the nine AMS radiocarbon dates and the assignment of a modern age (AD 2010) to the surface of the mallin was perfomed by using TILIA software (Grimm, 2012) applying a cubic smoothing spline interpolation. The $1200 \pm 30{ }^{14} \mathrm{C}$ years BP date was excluded because it forces the model age, thereby producing an abrupt change in sedimentation rate, without any sedimentological counterpart. Tephra layers were not subtracted to perform the age-depth model given that the preliminary analysis revealed that they were not pure volcanic ash but rather mixed with peat, so that instantaneous sedimentation could not be assumed.

Pollen analysis was performed on $1 \mathrm{~cm}^{3}$ of sediment samples taken at $8-\mathrm{cm}$ intervals ( $125 \mathrm{yr}$ median resolution). Pollen extraction from the sediments (Faegri and Iversen, 1989) was done following standard laboratory techniques including $\mathrm{KOH} 10 \%$, sieving ( $120 \mu \mathrm{m}$ mesh), hot HF $40 \%$ $\left(80^{\circ} \mathrm{C}\right)$, and acetolysis, followed by ultrasonic treatment. Tablets of the exotic spore Lycopodium clavatum were added to each sample to calculate pollen concentration (grains $\mathrm{cm}^{-3}$ ) (Stockmarr, 1971). The basic pollen sum for each level includes at least 300 terrestrial pollen grains. Pollen percentages of terrestrial taxa were based on the sum of trees, shrubs, herbs and grasses. Cyperaceae (paludal) and Pteridophytes - Polypodiaceae (Blechnum type) - taxa percentages were calculated from a supersum that included the basic pollen sum and the sum of paludal taxa or the of sum ferns, respectively. CONISS cluster analysis (Grimm, 1987) was performed to divide the sequence into zones of similar pollen composition, considering all local terrestrial pollen taxa $>2 \%$.

Macroscopic charcoal particles were analyzed to reconstruct the local fire regime at Mallín El Embudo. Two $\mathrm{cm}^{-3}$ of sediment at contiguous $1 \mathrm{~cm}$-intervals were sieved through 125 and $250 \mu \mathrm{m}$ mesh following methods outlined by Whitlock and Larsen (2001). Both charcoal fractions $(125$ and $250 \mu \mathrm{m})$ were tallied in gridded Petri dishes and identified at $10-40 \times$ magnification under a stereomicroscope. Grass particles were differentiated from wood charcoal based on the reference charcoal samples from the study area and published references (Umbanhowar and Mcgrath, 
Table 1. AMS radiocarbon dates from composite core EE0110 from Mallín El Embudo.

\begin{tabular}{lllrrrr}
\hline Lab code & Sample & Material & $\begin{array}{r}\text { Accumulated } \\
\text { depth }(\mathrm{cm})\end{array}$ & $\begin{array}{r}\text { Age } \\
\left({ }^{14} \text { C yr BP } \pm 1 \sigma \text { error }\right)\end{array}$ & $\begin{array}{r}\delta 13 C \\
(\%)\end{array}$ & $\begin{array}{r}\text { Age } \\
(\mathrm{cal} \mathrm{yr} \mathrm{BP})\end{array}$ \\
\hline UGAMS 13761 & EE0110BT1 25-26 & seeds & 25 & $140 \pm 20$ & -26.6 \\
UGAMS 13756 & EE0110AT2 9-10 & seeds & 62 & $1200 \pm 30$ & -27.2 \\
UGAMS14918 & EE0110AT3 5-6 & charcoal & 154 & $1610 \pm 40$ & -26.4 \\
UGAMS 13757 & EE0110AT3 13-14 & plant macro-remains & 162 & $1860 \pm 20$ & -28.7 \\
AA96425 & EE0110AT4 27-28 & peat & 266 & $4076 \pm 40$ & -30.3 \\
UGAMS 13759 & EE0110AT7 69-70 & wood & 585 & $8670 \pm 30$ & -27.7 \\
UGAMS 13760 & EE0110AT8 86-87 & peat & 699 & $9720 \pm 30$ & -27.9 & 1743 \\
AA96426 & EE0110AT9 27-28 & bulk sediment & 740 & $9879 \pm 69$ & -26.9 & 1130 \\
UGAMS 8375 & EE0110At9 96-97 & gyttja & 809 & $11100 \pm 35$ & -28.6 & 12997 \\
\hline
\end{tabular}

1998; Enache and Cumming, 2006). Charcoal concentration (particles $\mathrm{cm}^{-3}$ ) was calculated from raw data and then interpolated to 16 year bins (median temporal resolution of the record; yr sample ${ }^{-1}$ ) using the CharAnalysis software (Higuera et al., 2009, 2010) to calculate charcoal accumulation rate (CHAR; particles $\mathrm{cm}^{-2}$ year $^{-1}$ ). Two components from the charcoal series were distinguished: the background component (CBACK; extra-local or regional fire signal and secondary charcoal deposited in years without fires) and the peak component (CPEAK; local fire episode signal) (Long et al., 1998; Higuera et al., 2007). The CBACK was calculated by applying a regression method of locally weighted scatterplot smoothing (LOWESS) robust to outliers considering a window width of 1000 years which allowed the signal to noise index and the goodness-of-fit ( $P$-value) between the empirical and modeled noise distributions to be maximized (Higuera et al., 2009, 2010). The CPEAK was calculated as the interpolated difference between the CBACK and the CHAR. Given that the CPEAK presents a noise component, a Gaussian mixture model was used to identify the noise of the distribution choosing the 95th percentile. The 95th percentile is more suitable to detect small peaks in charcoal records from mallines given that otherwise they would be included within the background component (Holz et al., 2012). The fire-episode magnitude $\left(\mathrm{cm}^{-2}\right.$ peak $\left.{ }^{-1}\right)$ and the fire-episode frequency based on a 1000 year moving window were also calculated. A grass-to-total-charcoal ratio based on the CHAR values was calculated to analyze the severity of fires. High ratio values (low severity, >0.5) reflect surface fires, whereas low grass-to-total-charcoal ratio values (high severity, < 0.5) indicate crown fires (Whitlock et al., 2006).

\section{Results}

\subsection{Stratigraphy and chronology}

An 844 cm-long composite sediment core from Mallín El Embudo was obtained by overlapping cores EE0110B1 and EE0110A2-A10 (Fig. 2) based on the LOI data correlation.
The composite core consists of grey clays $(817-844 \mathrm{~cm})$ related to an ice-dammed lake, gyttja $(813-817 \mathrm{~cm})$ associated with organic lacustrine sedimentation and peat from $813 \mathrm{~cm}$ to the top of the core associated with the development of a mallín. Seven clastic layers are intermingled with the peat: four tephra layers (a, 170-176 cm; b, 246-274 cm; $\mathrm{h}, 552-553 \mathrm{~cm} ; \mathrm{j}, 741-742 \mathrm{~cm}$ ) and three siliciclastic (sandysilt) layers (c-f, 384-407 cm; g, 525-532 cm; i, 686-687 cm) (Fig. 2). Microscopic volcanic particle analysis combined with the stratigraphic/chronologic position of tephra layers indicates the likely possible tephra source volcanoes and eruptions are Melimoyu (MEL $2 \leq 1750 \pm 80{ }^{14} \mathrm{C}$ years BP, layer a), Hudson $\left(\mathrm{H}_{2} \sim 3600 \pm 200{ }^{14} \mathrm{C}\right.$ years $\mathrm{BP}$; Naranjo and Stern, 1998; layer b) Mentolat (MEN 1, layer h) and some volcano from the Liquiñe-Ofqui fault zone (layer $\mathrm{j}$ ) (Stern, personal communication, 2013).

Loss-on-ignition data mirror the lithological changes from the Mallín El Embudo core (Fig. 2). Organic percentages show a major change from $5 \%$ associated with the grey clays $(817-844 \mathrm{~cm})$ and $15 \%$ corresponding to gyttja $(813-$ $817 \mathrm{~cm})$, to values relatively constant over $85 \%$ associated with peat $(0-813 \mathrm{~cm})$. A significant decrease of organic percentages ranging from 5 to $60 \%$ and represented as maximum peaks of inorganic content $\left(\mathrm{gr} \mathrm{cm}^{-3}\right)$ reflects the clastic (tephra and siliciclastic) layers intermingled with the peat.

The age-depth model of Mallín El Embudo (Fig. 3) suggests a continuous deposition since $13 \mathrm{ka}$, but some sedimentation rate variations are found along the core. The highest sedimentation rates $\left(1.3\right.$ and $\left.0.6 \mathrm{~cm}_{\text {year }}{ }^{-1}\right)$ are recorded around 11.2 and $0.1 \mathrm{ka}$, whereas the lowest $\left(0.03 \mathrm{~cm} \mathrm{year}^{-1}\right)$ are recorded at $2 \mathrm{ka}$. On the contrary, the resolution of the record varies between 3 year $\mathrm{cm}^{-1}$ at 11.2 and $0.1 \mathrm{ka}$ to 36 year $\mathrm{cm}^{-1}$ around $2 \mathrm{ka}$.

\subsection{Pollen record}

The pollen record from Mallín El Embudo is presented in Fig. 4 showing the dominant taxa percentages. Pollen zones (EE1-6) were defined by CONISS results and ecological criteria. 


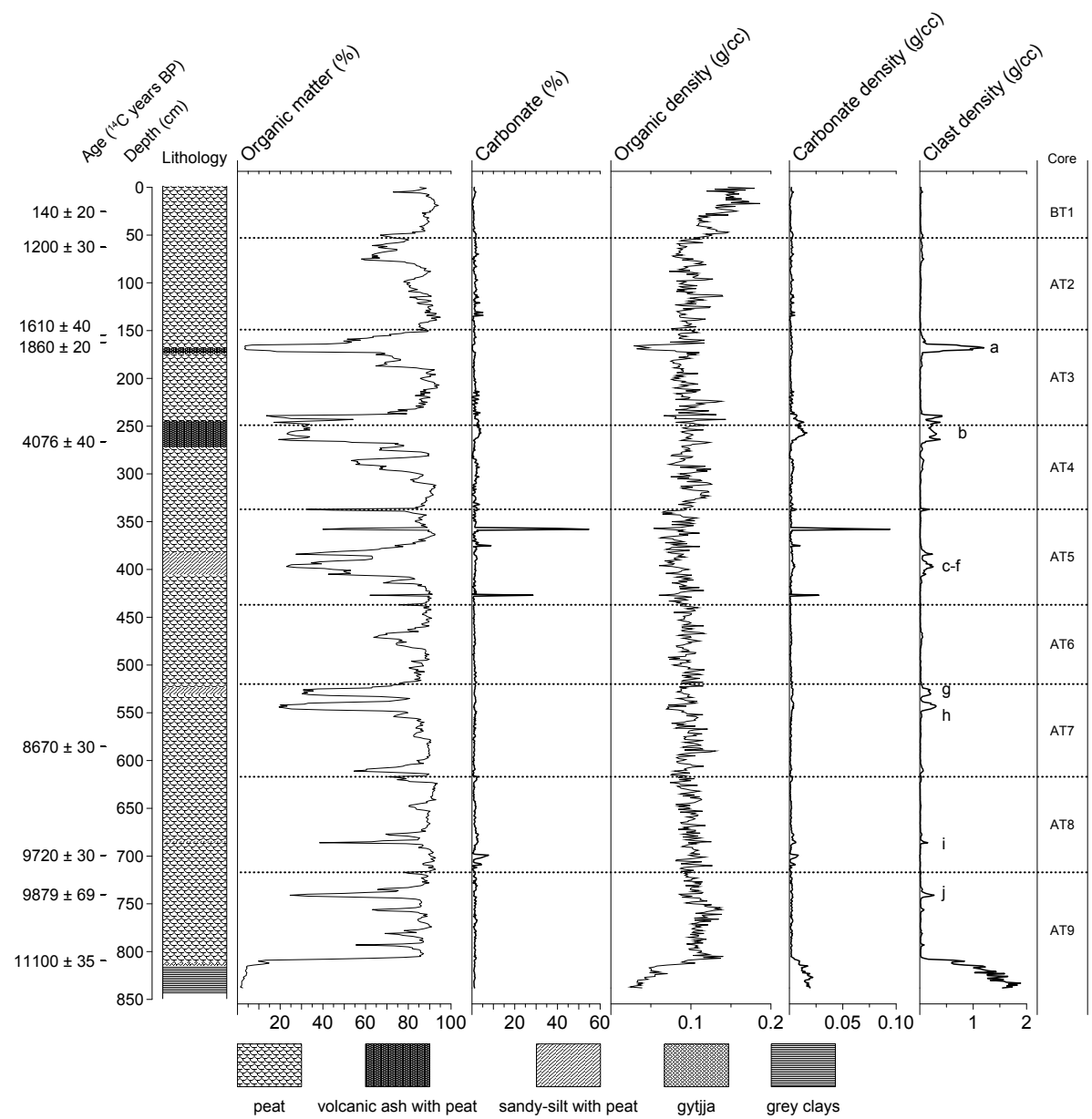

Figure 2. Stratigraphic column of Mallín El Embudo composite core, radiocarbon dates and loss on ignition results. Letters represent clastic layers and dashed horizontal lines indicate the core segment boundaries.

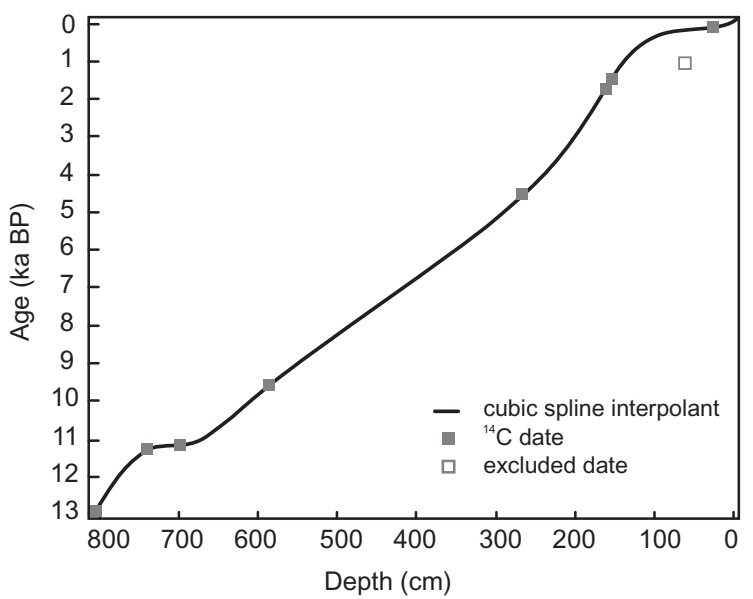

Figure 3. Age-depth model from Mallín El Embudo based on eight calibrated AMS radiocarbon dates. The date excluded from the agedepth model is represented as an open square.
- Zone EE1 (13-11.2 ka; $813-720 \mathrm{~cm}$ depth) is dominated by Poaceae $(90-40 \%)$ along with Valerianaceae (Valerianella type; 30-5\%), Empetrum rubrum $(<5 \%)$, Asteraceae subf. Asteroideae (Chiliotrichum included, $<5 \%$ ) and Acaena $(<5 \%)$. Local forest taxa percentages such as Nothofagus dombeyi type, Misodendron and Escallonia as well as long-distance taxa such as Podocarpus remain below $25 \%$. Cyperaceae percentages vary between 80 to $30 \%$, whereas Polypodiaceae (Blechnum type) shows its maximum percentages around $80 \%$, towards the top of this zone.

- Zone EE2 (11.2-9.5 ka; 720-580 cm depth) is characterized by a major increase of Nothofagus dombeyi type above $35 \%$ that reaches maximum values $(75 \%)$ around 11.1 and $10.2 \mathrm{ka}$. Simultaneously, a concomitant decrease of Poaceae (45-10\%) and Valerianaceae ( $\mathrm{Va}$ lerianella type; $<10 \%)$ is recorded. Other forest taxa such as Misodendron, Escallonia and Podocarpus remain below $10 \%$, whereas percentages of shrubs like Asteraceae subf. Asteroideae (Chiliotrichum included, 


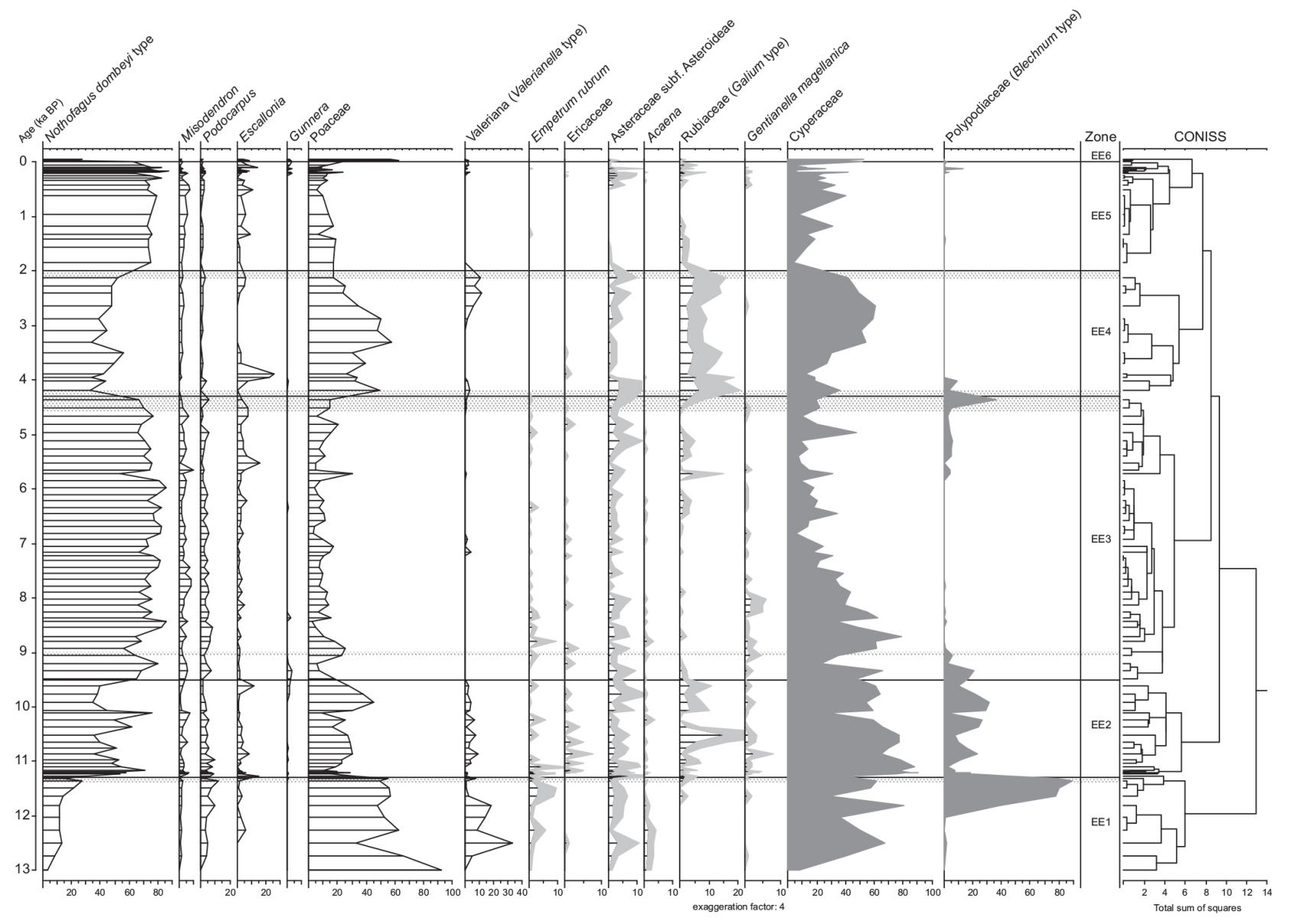

Figure 4. Percentage pollen diagram of Mallín El Embudo showing dominant taxa and CONISS analysis. Grey horizontal bands represent tephra layers.

$<10 \%)$ and herbs represented by Rubiaceae (Galium type; $<20 \%)$ and Gentianella magellanica $(<5 \%)$ increase. Cyperaceae values are the highest for the whole record fluctuating from 30 to $90 \%$, whereas Polypodiaceae (Blechnum type) values abruptly decrease below $30 \%$.

- Zone EE3 (9.5-4.2 ka; 580-260 cm depth) shows relatively constant percentages of Nothofagus dombeyi type $(85-55 \%)$ associated with other forest taxa such as Misodendron $(<10 \%)$, Escallonia $(<15 \%)$, Podocarpus $(<10 \%)$. Poaceae values decrease from $25 \%$ to $5 \%$, whereas Asteraceae subf. Asteroideae (Chiliotrichum included, $<10 \%)$ and Gentianella magellanica $(<5 \%)$ percentages remain similar to Zone EE2. A slight decrease of Nothofagus dombeyi type $(\sim 70 \%)$ and increase of Escallonia, Poaceae and Asteraceae subf. Asteroideae (Chiliotrichum included) is recorded after $5.7 \mathrm{ka}$. Cyperaceae shows a gradual decreasing trend from the base to the top of EE3, whereas Polypodiaceae (Blechnum type) diminishes to minimum values around
$9 \mathrm{ka}$ increasing again at the end of this zone around $5.7 \mathrm{ka}$.

- Zone EE4 (4.2-2.1 ka; $260-173 \mathrm{~cm}$ depth) exhibits a major decrease of Nothofagus dombeyi type (55-35\%) coupled with an increase of Poaceae (55-25\%) and Rubiaceae (Galium type; $<10 \%$ ) and a discrete peak of Escallonia up to $25 \%$ (3.9 ka). Misodendron $(<5 \%)$, Podocarpus ( $<5 \%)$ and Asteraceae subf. Asteroideae (Chiliotrichum included, $<5 \%$ ) remain steady. Cyperaceae values increase at $3.9 \mathrm{ka}$ from $20 \%$ up to $60 \%$ around $2.8 \mathrm{ka}$ and decrease $(25 \%)$ to the end of the zone, whereas Polypodiaceae (Blechnum type) declines to minimum percentages at the base of EE4.

- Zone EE5 (2.1-0.1 ka; $173-7 \mathrm{~cm}$ depth) is characterized by an increase of Nothofagus dombeyi type (85-55\%) associated with a Poaceae (20-5\%) decrease. Gunnera $(<5 \%)$, Escallonia $(<15 \%)$, Asteraceae subf. Asteroideae (Chiliotrichum included, $<5 \%$ ), Rubiaceae (Galium type; $<10 \%$ ) values increase after $0.4 \mathrm{ka}$, whereas Misodendron $(<5 \%)$ and Podocarpus $(<5 \%)$ 


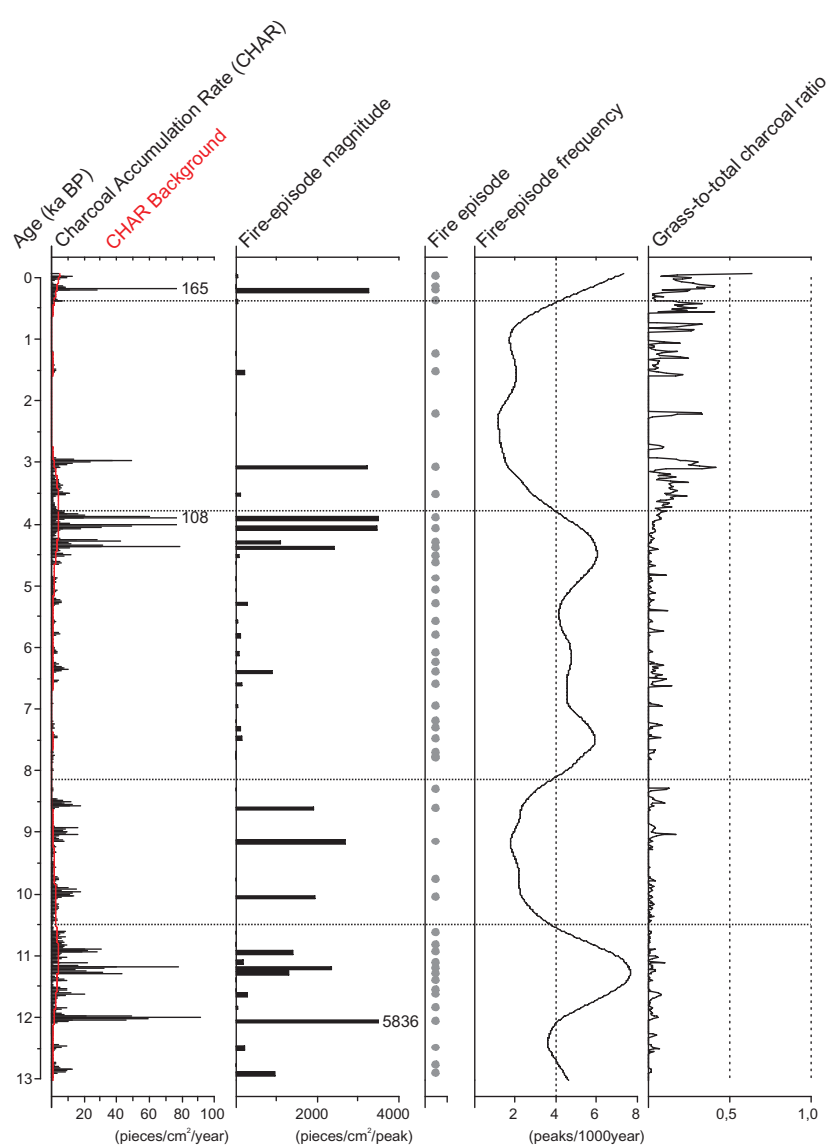

Figure 5. Charcoal record from Mallín El Embudo including charcoal accumulation rate (CHAR), fire-episode magnitude, fire episodes, fire-episode frequency and grass-to-total-charcoal ratio. The horizontal lines show the division of the record according to fire regime changes.

percentages diminish to the top of this zone. Cyperaceae values fluctuate between $40-10 \%$, showing minimum values around 1.9 and $0.5 \mathrm{ka}$.

- Zone EE6 (0.1 ka-present; 7-0 cm depth) presents a prominent decrease of Nothofagus dombeyi type (30$20 \%)$ coupled with an increase of Poaceae $(\sim 60 \%)$. No major changes of minor accompanying taxa such as Misodendron $(<5 \%)$, Escallonia ( $10 \%)$, Podocarpus $(<5 \%)$ occur, whereas Cyperaceae percentages reach peaks of $50 \%$.

\subsection{Charcoal record}

The Mallín El Embudo record shows millennial-scale trends with highly variable total charcoal accumulation rates (CHAR) and low background charcoal values (Fig. 5). A high signal-to-noise index (global SNI $=10.3$ ) allowed the noise to be separated from the fire episodes ( 49 events) with a high confidence level.
From 13 up to $10.5 \mathrm{ka}$ BP, the record suggests high fire-episode magnitude and maximum frequency (up to 7 peaks/1000 year). Low grass-to-total-charcoal ratio indicates high fire-episode severity related to crown fires.

The number of fire episodes decreases between 10.5 and $8.2 \mathrm{ka}$ BP but the fire-episode magnitude remains high, whereas the fire-episode frequency declines to less than 3 peaks $/ 1000$ year. The grass-to-total-charcoal ratio increases moderately remaining below 0.5 and suggesting the prevalence of crown fires.

From 8.2 to $3.8 \mathrm{ka} \mathrm{BP}$, the record is characterized by an increasing CHAR trend showing high fire-episode frequency ( $>4$ fires/1000 year) and high fire-episode magnitude centered around $4.5-3.8 \mathrm{ka}$. A moderate grass-to-total-charcoal ratio rise towards 3.8 ka suggests surface fires (low severity) increase.

Between 3.8 and $0.4 \mathrm{ka} \mathrm{BP}$, the fire-episode frequency diminishes up to 2 fires per 1000 years and the magnitude decreases. After $1.5 \mathrm{ka}$, the grass-to-total-charcoal ratio increases showing highly variable values that suggest a transition from crown to surface fire episodes.

The last $0.4 \mathrm{ka}$ are characterized by high CHAR values and high fire-episode frequency but the variable peak magnitude and an increasing trend of the grass-to-total-charcoal ratio suggest the occurrence of surface fires (low severity).

\section{Discussion}

\subsection{Mallín El Embudo}

\subsubsection{Environmental reconstruction}

The sedimentary and local pollen taxa record of Mallín El Embudo (Figs. 2, 4) reveals three different depositional environments: (1) grey clays associated with low organic percentages indicate that the Mallín El Embudo basin was flooded by a proglacial lake that would have occupied the middle Río Cisnes valley before $13 \mathrm{ka}$; (2) lacustrine organic mud (gyttja) related to an increase in organic percentages combined with a rise of Cyperaceae values and the absence of aquatic taxa between 13 and $12.8 \mathrm{ka}$ indicate the brief development of a shallow lake; and (3) the presence of decomposed peat associated with maximum organic percentages and the continuous presence of Cyperaceae suggest the development of a mallin similar to the one present after $12.8 \mathrm{ka}$.

\subsubsection{Vegetation and fire dynamics}

The Mallín El Embudo record reflects a highly dynamic history of vegetation in the middle Río Cisnes valley (MRCV) since 13 ka (Fig. 4).

Open landscapes dominated by grasses (Poaceae) accompanied by herbs (Valerianaceae) and shrubs - Asteraceae subf. Asteroideae (Chiliotrichum included) and Empetrum - and isolated Nothofagus patches prevailed in the MRCV 
between 13 and $11.2 \mathrm{ka}$ (Fig. 4). Modern pollen surveys in southern Patagonia $\left(50^{\circ} \mathrm{S}\right)$ show that similar pollen assemblages reflect the presence of grass steppes under mean annual precipitation lower than $500 \mathrm{~mm}$ (Mancini et al., 2012). Nothofagus percentages would reflect pollen locally produced within the forest patches but also long distance transport from the deciduous and evergreen Nothofagus forest located to the west, along the Pacific coast or in the Chonos Archipelago (Montade et al., 2013; Haberle and Bennett, 2004; Bennett et al., 2000). The presence of Acaena indicates ground soil conditions under still unstable postglacial landscapes in the MRCV by this time (Fig. 4). These pollen assemblages therefore indicate lower effective moisture (drier and colder conditions) than present but also indicate that landscape configuration after glacial retreat in the RCV was still ongoing. On the other hand, a fern - Polypodiaceae (Blechnum type) - peak and the concomitant decrease of paludal taxa (Cyperaceae) towards 11.2 ka suggest a trend towards drier local conditions in Mallín El Embudo (Fig. 4). It is probable that higher summer temperatures would have produced short-term oscillations in the mallin water table level thus exposing larger shore areas and favoring colonization by ferns at the expense of paludal taxa. Besides, an increase in fire-episode frequency around $11.2 \mathrm{ka}$ (Fig. 5) supports the latter given that fire occurrence in Nothofagus deciduous forest in central Chilean Patagonia is dependent today on warm and dry spring-summers (Holz and Veblen, 2012; Holz et al., 2013).

A major decrease of Nothogafus and Misodendron percentages combined with the increase of understory taxa percentages like Escallonia, Asteraceae subf. Asteroideae (Chiliotrichum included), Rubiaceae (Galium type) and Gentianella magellanica (Fig. 4), indicate the development of an open Nothofagus forest in the MRCV between 11.2 and $9.5 \mathrm{ka}$. These pollen assemblages suggest an effective moisture increase but still below modern values. The proliferation of Cyperaceae at expense of ferns after $11.2 \mathrm{ka}$ would reflect a reduction of exposed shore areas regarding the latter period, supporting therefore the idea of an increase in moisture (Fig. 4). Highly fluctuating values of Nothofagus and understory taxa during this period indicate a quite dynamic forest. The high frequency and magnitude of crown fire episodes peaking around $11.2 \mathrm{ka} \mathrm{(Fig.} \mathrm{5)} \mathrm{would} \mathrm{be} \mathrm{related} \mathrm{to} \mathrm{this} \mathrm{post-}$ glacial development of the forest (and hence fuel availability) coupled with the establishment of seasonal climatic conditions. Thus, wet winters (but still drier than present) may have promoted the forest development, whereas warm and dry spring-summer conditions might have favored the drying of the fuel to be burned. High percentages of Rubiaceae (Galium type; Fig. 4) support the forest disturbance due to fire activity given that they are known as soil-stored seed plants from the forest understory that sprout after frequent fire events (Vidal and Reif, 2011).

Between 9.5 and $5.7 \mathrm{ka}$, high Nothofagus percentages associated with low values of understory taxa and Poaceae re- flect the development of a closed forest indicating an increase in effective moisture (Fig. 4). Around $5.7 \mathrm{ka}$, a decrease in Nothofagus percentages associated with increased values of Escallonia, Poaceae and Asteraceae subf. Asteroideae (Chiliotrichum included) suggests a slight opening of the forest canopy concomitant with a decrease of Cyperaceae values and an increase of fern percentages that peak around $4.2 \mathrm{ka}$ (Fig. 4). Thus, mallin local indicator trends associated with an increase of understory forest taxa at the expense of trees suggest a more open forest canopy which indicates a slight decrease of effective moisture between 5.7 and $4.2 \mathrm{ka}$. Between 9.5 and $4.2 \mathrm{ka}$, the charcoal record indicates a high frequency and low magnitude of crown fire episodes (Fig. 5). It is probable that the development of a closed forest (high fuel availability) under increased effective moisture conditions combined with moderate dry summers may have triggered persistent yet low magnitude crown fires that did not severely affect the forest.

A major decrease of Nothogafus and Misodendron percentages together to the increase of understory taxa such as Asteraceae subf. Asteroideae (Chiliotrichum included), Rubiaceae (Galium type) and Poaceae between 4.2 and $2 \mathrm{ka}$ (Fig. 4) indicates a sudden vegetation change to open forest conditions. This change is concomitant with an increase in the frequency and magnitude of crown fire episodes (Fig. 5) and is preceded by the $\mathrm{H}_{2}$ eruption tephra layer deposition (Fig. 4). Even though the onset of forest opening would have occurred around $5.7 \mathrm{ka}$ (as explained above), the increase of fire-episode frequency and magnitude and the tephra deposition may have enhanced the vegetation change. However, the relative contribution of climate, fire and volcanism on the forest opening is quite difficult to identify, since the slight trend towards drier conditions, high fire-episode occurrence, and ashfall deposition would result in a similar forest change canopy opening (death of the tree stratum) concomitant with the appearance of different understory taxa.

A trend towards surface fire episodes in the MRCV between 4.2 and $3 \mathrm{ka}$ (Fig. 5) would respond to a major development of understory vegetation at expense of the tree stratum highly affected by crown fire episodes during the previous centuries. Since $2 \mathrm{ka}$, Nothofagus percentages increase indicating the presence of a closed forest but more open from that of the early/mid-Holocene as indicated by the higher percentages of Escallonia and Poaceae (Fig. 4). These pollen assemblages suggest the establishment of modern climatic conditions probably associated with interannual or interdecadal fluctuations in moisture given that the increased occurrence of surface fire episodes is conditioned by short-term fluctuations in moisture favoring fuel growing and later desiccation to be burned (Holz and Veblen, 2013). However, fire occurrence could be partially due to human agency given that hunter-gatherer occupations have been recorded at different locations along the whole RCV between 2.8 and $2.4 \mathrm{ka}$, when a change in mobility and settlement patterns occurred (Méndez and Reyes, 2008). 
Since $0.4 \mathrm{ka}$, a quite dynamic forest occurred (a shift from open to closed forest and vice versa) represented by highly variable Nothofagus percentages as well as the presence of understory taxa and grasses related to an increase in the frequency of less severe fires (Fig. 4).

The last $0.1 \mathrm{ka}$ is characterized by an abrupt decline of Nothofagus at the expense of Poaceae (Fig. 4) reflecting the clearance of the forest during the European colonization. Historical chronicles indicate that permanent settlements at the MRCV, close to the Mallín El Embudo area, were not established until 1930, but logging and burning began in the early 20th century when the Río Cisnes Ranch was established (Martinic, 2005).

\subsection{Regional environmental and paleoclimatic dynamics since the Late Glacial}

\subsubsection{Late Glacial}

An early deglaciation timing (ca. 23-16 ka) characterizes eastern central Chilean Patagonia (CCP) (Douglass et al., 2006; Kaplan et al., 2004; Hein et al., 2010) if compared to the proposed age for the onset of the deglaciation of the Patagonian ice cap after the first warming pulse around $17.5 \mathrm{ka}$ (McCulloch et al., 2000). Thus, the basal ages and the beginning of organic sedimentation from Lago Shaman (19 ka; de Porras et al., 2012) and Mallín Pollux (18 ka; Markgraf et al., 2007) evidence that eastern CCP areas were free of ice by 19-18 ka, whereas glacial retreat associated with a proglacial lake at Lago Augusta area $\left(47^{\circ} \mathrm{S}\right.$, Fig. 1a) occurred $\sim 2 \mathrm{ka}$ later (16 ka) probably due to its southern location (Villa-Martínez et al., 2012). At western CCP, the beginning of organic sedimentation in lakes indicates minimum ages for ice retreat around 16.3-15.9 ka at the Chonos Archipelago (Haberle and Bennett, 2004) and 17.3-17.2 ka in the Taitao Peninsula (Bennett et al., 2000). The differences in the deglaciation timing between eastern and western CCP would be related to the existence of a locally nourished ice cap in the Taitao Peninsula that would have been completely independent from the Patagonian Ice Cap (Glasser et al., 2008).

Pollen records from eastern CCP - Lago Shaman (de Porras et al., 2012) and Mallín Pollux (Markgraf et al., 2007) - indicate the development of grass-shrub steppes between 19 and $15 \mathrm{ka}$ (Fig. 6). On the contrary, the pollen record of Lago Augusta was interpreted as showing local, scattered low-density populations of evergreen Nothofagus (probably $N$. betuloides) in an open landscape dominated by Poaceae and Ericaceae between 16 and 15.6 ka (Fig. 6; Villa-Martínez et al., 2012). These authors discussed that the evergreen forest signal is local and not attributable to long-distance pollen transport from forests located in western CCP. Besides, they proposed that similar pollen assemblages found in the Mallín Pollux record (and interpreted as an extra-local signal by Markgraf et al., 2007) would also reflect the local de-

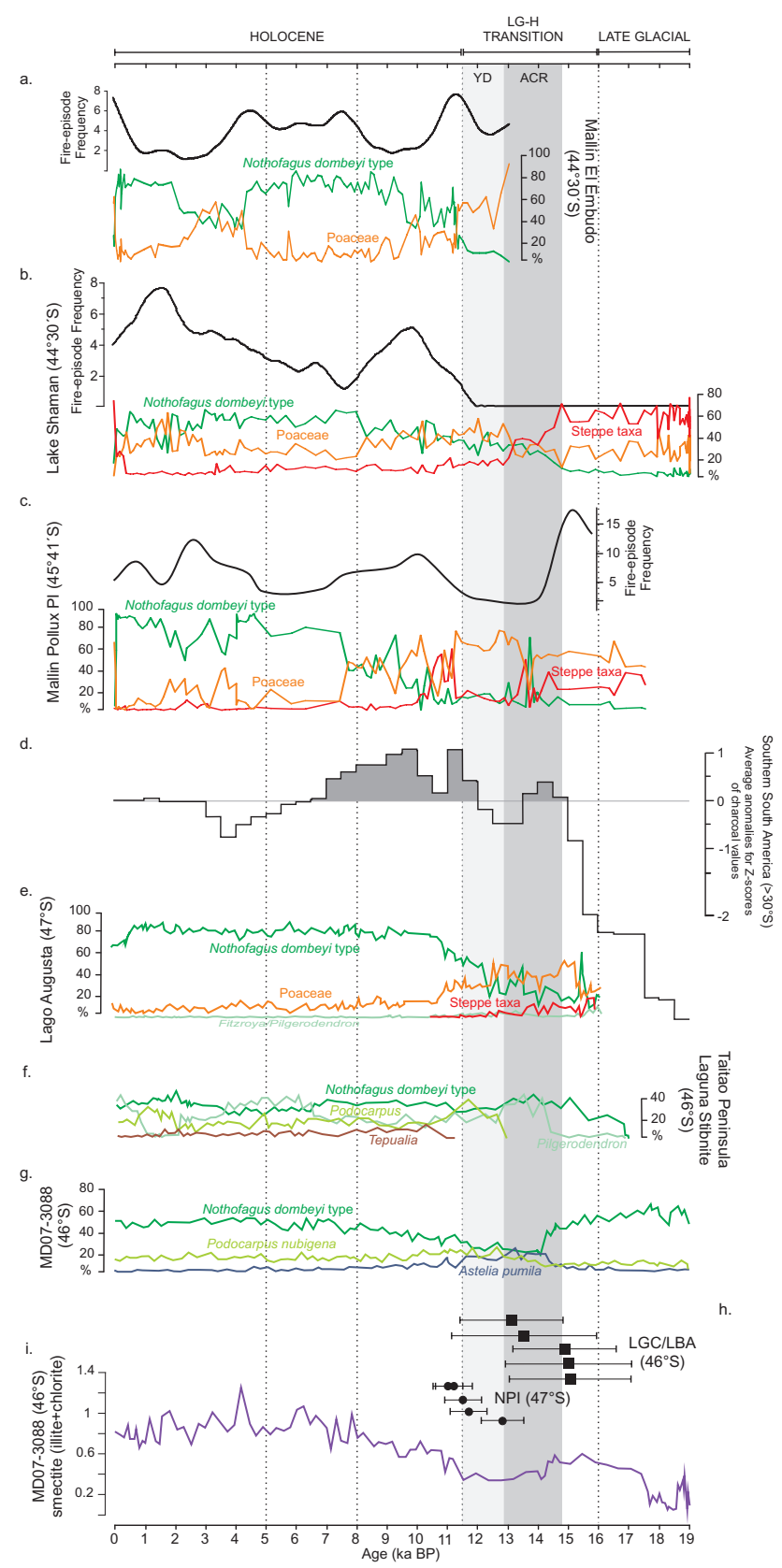

Figure 6. Integration of selected paleoenvironmental data from central Chilean Patagonia since the Late Glacial showing fire-episode frequency curve and summarized pollen diagram (\%) from (a) Mallín El Embudo, (b) Lago Shaman (de Porras et al., 2012) and (c) Mallín Pollux (Markgraf et al., 2007); (d) summary of paleofire activity in western South America ( $>30^{\circ} \mathrm{S}$, Power et al., 2008); summarized pollen diagram (\%) from (e) Lago Augusta (Villa-Martinez et al., 2012); (f) Laguna Stibnite (Bennett et al., 2000) and (g) MD07-3088 marine core (Montade et al., 2013); (h) surface exposure ages of Late Glacial moraines at LBA/LGC (Douglass et al., 2006) and NPI (Glasser et al., 2012); (l) smectite/(illite+chlorite) index from MD07-3088 marine core (Siani et al., 2010). Grey vertical lines represent ACR and YD chronozones. 
velopment of isolated patches of evergreen forest. However, modern pollen assemblages from the evergreen Nothofagus forest (Haberle and Bennet, 2001) and a transect along the Río Cisnes valley $\left(44^{\circ} 40^{\prime} \mathrm{S}\right.$, Maldonado, unpublished data) indicate that values $<10 \%$ of evergreen forest taxa found in Lago Augusta, Mallín Pollux and Lago Shaman records during early deglaciation stages may reflect long-distance transport, probably from forest refugia located along the Pacific coast (Montade et al., 2013; Haberle and Bennett, 2004; see discussion below). Besides, pollen assemblages of Lago Augusta dominated by Poaceae associated with steppe taxa like Ericaceae, Acaena, Asteraceae subf. Asteroideae, Caryophyllaceae and Perezia-type between 16 and $15.6 \mathrm{ka}$ are quite similar to those recorded in Mallín Pollux and Lago Shaman (Fig. 6) and would reflect grass-shrub steppes.

In western CCP, the Taitao Peninsula and the Chonos Archipelago (Bennett et al., 2000) pollen records show the development of Ericaceae heathlands and grasslands after deglaciation (17.3-16.5 ka). The pollen record from a marine core offshore Taitao Peninsula (MD07-3088, Fig. 1a) reflects the presence of a subantarctic parkland, characterized by Nothofagus-Poaceae communities accompanied by Apiaceae, Gunnera, Asteraceae and Empetrum-Ericales along the Chilean coast around 22-17.6 ka (Fig. 6; Montade et al., 2013). A rapid replacement of heathlands and grasslands by Nothofagus-dominated forests in Taitao Peninsula and Chonos Archipelago and the pollen signal of NothofagusPoaceae communities up to $17.6 \mathrm{ka}$ in MD07-3088 record suggest the presence of forest refugia during the LGM along the western coastal margin probably partially free of ice (Haberle and Bennett, 2004; Montade et al., 2013).

Vegetation in CCP therefore reflects colder and drier climatic conditions than present during the Late Glacial. These paleoecological inferences partially coincide with the smectite/illite+chlorite index from MD07-3088 marine core, which suggest lower precipitation than present up to $18 \mathrm{ka}$ and a slight increasing trend (but still under modern values) since then (Fig. 6; Siani et al., 2010). Taken together, the paleoecological and glaciological data from CCP support the hypothesis of an equatorward position of the southern westerlies around $41^{\circ} \mathrm{S}$ during the Last Glacial Maximum (e.g., Moreno et al., 1999; Rojas et al., 2009).

\subsubsection{Late Glacial-Holocene transition}

Evidence of cold reversal events like the Antarctic Cold Reversal (ACR; 14.5-12.8 ka) and Younger Dryas (YD; 13$11.2 \mathrm{ka}$ ) in central Chilean Patagonia is scarce and inconclusive. A late glacial readvance represented by the Menucos moraine in Lago Buenos Aires/Lago General Carrera $\left(46^{\circ} \mathrm{S}\right.$, Fig. 1a) around $14 \mathrm{ka}$ (Fig. 6; Douglass et al., 2006) and a frontal moraine in the middle Río Cisnes valley (Fig. 1b) indirectly dated $\sim 13$ ka occur simultaneously with the ACR. However, recent results of glacial geomorphology in the eastern North Patagonian Icefield $\left(47^{\circ} \mathrm{S}\right)$ indicate glacier advances synchronously with the YD chronozone (Fig. 6; Glasser et al., 2012).

The ACR or YD signal is not reflected by terrestrial pollen records in central Chilean Patagonia (Fig. 6; Bennett et al., 2000; de Porras et al., 2012; Markgraf et al., 2007; Villa-Martínez et al., 2012). Eastern CCP records point out steppe-dominated vegetation with scattered Nothofagus trees, whereas the rainforest development with Nothofagus, Pilgerodendron and Podocarpus occurred in western CCP (Haberle and Bennett, 2004). CCP vegetation suggests an increase in precipitation under the warming trend that started deglaciation. The increasing trend of the smectite/illite+chlorite index from the MD07-3088 core also supports a precipitation increase (Siani et al., 2010). Furthermore, a magellanic moorland expansion (mainly Astelia pumila) in the Taitao Peninsula between 14.5 and 12.8 ka reflected in MD07-3088 pollen record (Fig. 6) was interpreted as an increase in precipitation but associated with a slight cooling (or a pause of warming) that is synchronous to the ACR (Montade et al., 2013).

In summary, the inconclusive evidence regarding the ACR or YD reflection in CCP pinpoints a new issue that needs further multi-proxy research. Terrestrial records do not show any temperature change except for the warming trend that characterizes deglaciation whereas the pollen record from the marine core reflects a slight cooling synchronous with the ACR chronozone (Montade et al., 2013). Regarding the SW' behavior, two possible scenarios were therefore stated. On one hand, a gradually increased level of moisture recorded in terrestrial records supports the idea of a southward migration of the SW up to its modern position about $1.5 \mathrm{ka}$ after the LGM termination (Markgraf et al., 1992; McCulloch et al., 2000). On the other hand, the restricted expansion of the magellanic moorland in the Taitao Peninsula area during the ACR and only recorded in the MD07-3088 pollen record was interpreted as a southward migration of the SW from their LGM position but interrupted by a northward shift during the ACR (Montade et al., 2013). This would have resulted in an intermediate position of the SW between their equatorward LGM position and their Holocene (similar to modern) position (Montade et al., 2013).

\subsubsection{Early Holocene}

Around $11.5 \mathrm{ka}$, central Chilean Patagonia records show a trend towards similar to modern environments indicating the onset of the Holocene. Eastern CCP records show the gradual development of Nothofagus deciduous forest - Mallín El Embudo; Mallín Pollux (Markgraf et al., 2007); Lago Augusta (Villa-Martínez et al., 2012) - or the Nothofagus forest-grass steppe ecotone (Lago Shaman), as well as evergreen Nothofagus forest with Podocarpus, Pilgerodendron and Tepualia and Weinmannia established in the Taitao Peninsula and the Chonos Archipelago in western central Chilean Patagonia (Fig. 6). The development of these 
plant communities in eastern CCP suggests an increase in precipitation but still under modern values. The increase in Tepualia and Weinmannia (heliophytic taxa) at the expense of cold-tolerant taxa in Taitao Peninsula and Chonos Archipelago forest, also recorded in the MD core (Fig. 6), suggests warmer conditions since $\sim 11.7 \mathrm{ka}$. Besides, simultaneous local change in eastern CCP records reflected as a fern peak (Mallín El Embudo), the sudden dominance of paludal over aquatic taxa (Lago Shaman and Mallín Pollux) and the presence of laminated carbonates (higher evaporation rates; Lago Augusta) indicate increased summer temperatures around $11.5 \mathrm{ka}$.

Charcoal data indicate that the early Holocene was characterized by a high fire-episode frequency in eastern (Mallín El Embudo, Mallín Pollux, Lago Shaman) or western (Taitao Peninsula) CCP (Fig. 6). This pattern correlates to that found in most Patagonian charcoal records south of $40^{\circ} \mathrm{S}$, which show widespread fire activity (positive anomalies) between 12 and $8 \mathrm{ka}$ that was related to climatic drivers (Fig. 6; Whitlock et al., 2007; Moreno et al., 2010b; Power et al., 2008). However, the widespread presence of humans at the eastern flank of the Andes during this period (Méndez, 2014; Prates et al., 2013) implies that they should be also considered as a possible ignition agent contributing to the increased fire activity.

In combination, vegetation and charcoal records indicate a slight increase in precipitation and/or increased summer temperatures. Increased precipitation would be due to weaker and poleward-shifted SW as a consequence of a reduction in the latitudinal temperature gradient driven by higher-thanpresent insolation in southern high latitudes (de Porras et al., 2012; Liu et al., 2003; Whitlock et al., 2007).

\subsubsection{Mid-Holocene}

The mid-Holocene was characterized by the establishment of similar-to-modern vegetation (de Porras et al., 2012) in CCP. Eastern CCP sites show the easternmost position of the Nothofagus forest-steppe ecotone (Lago Shaman) and the closest deciduous forest development (Mallín El Embudo and Mallín Pollux) during the whole Holocene (Fig. 6). Evergreen forest of Nothofagus, Pilgerodendron and Tepualia established around 7.6 ka in Chonos Archipelago and Taitao Peninsula and persisted until the present (Fig. 6; Haberle and Bennett, 2004; Montade et al., 2013).

Charcoal records from eastern CCP sites indicate low-tomoderate frequency of low-magnitude fire episodes during the mid-Holocene. As explained for Mallín El Embudo (see Sect. 5.1.2), fuel availability was abundant, but the increased effective moisture conditions combined with moderate dry summers may have triggered persistent but low magnitude fire episodes that did not severely affect the forests.

Taken together, pollen and charcoal records from CCP suggest wetter conditions than present coupled with unmarked seasonality (moderate dry summers) con- ditions, which match with increasing values of the smectite/illite+chlorite index (MD07-3088 core) that also suggest a slight gradual increase of precipitation (Fig. 6; Siani et al., 2010).

The synchronous increase in precipitation in CCP as well as in northern (e.g., Abarzúa et al., 2004; Moreno, 2004; Moreno and León, 2003) and southern Patagonia (e.g., Moreno et al., 2010a) reflects an intensification of the southern westerlies during the mid-Holocene that will be due to a steepening of the pole-equator ocean gradient around $6 \mathrm{ka}$ according to climate modeling results (Rojas and Moreno, 2009).

\subsubsection{Late Holocene}

The late Holocene ( $5 \mathrm{ka}$ to the present) was characterized by an apparent breakdown in synchronicity of vegetation and fire dynamics between western and eastern CCP records (except for Lago Augusta) (Fig. 6). Whilst western CCP records do not show major changes since the mid-Holocene, eastern CCP sites reflect a quite dynamic picture (Fig. 6). A sudden opening of the deciduous forest canopy occurred synchronously around $\sim 4.2-4.0 \mathrm{ka}$ in Mallín El Embudo and Mallín Pollux (Markgraf et al., 2007) apparently climatically driven (due to a trend toward drier conditions since $5.7 \mathrm{ka}$ ) but probably enhanced by the $\mathrm{H}_{2}$ tephra deposition and high fire activity. The combined effect of climate, ash deposition and fire on vegetation seems to have lasted up to $2 \mathrm{ka}$ when both records show the recovery of the deciduous forest. A retraction of the forest-steppe ecotone is recorded in the Lago Shaman record between 3 and $1.3 \mathrm{ka}$ and associated with high fire activity.

High fire activity characterized most eastern CCP records during the late Holocene, although asynchronies among records are evident (Fig. 6). These asynchronies could be related to the complex climate-fire-vegetation relationships occurring at the different vegetation units (Withlock et al., 2010), but also as a consequence of widespread and recurrent human activity recorded in central Chilean Patagonia through the late Holocene (Mena and Stafford, 2006; Méndez and Reyes, 2008; Méndez et al., 2011; Reyes et al., 2009). High fire occurrence during the late Holocene in CCP does not match the regional fire pattern (Fig. 6; Power et al., 2008) but is consistent with the fire dynamics regionalization proposed by Withlock et al. (2007).

In summary, terrestrial and marine (smectite/illite+chlorite index) records suggest the establishment of slightly drier conditions than during the mid-Holocene around $5 \mathrm{ka}$ (de Porras et al., 2012; Siani et al., 2010). About $2 \mathrm{ka}$, the recovery of the deciduous forest in CCP (Mallín El Embudo and Mallín Pollux records, Fig. 6) suggests a shift to slightly wetter conditions than before and similar to the present ones under interannual or decadal climatic variability evidenced by the occurrence of 
surface fires, which are actually conditioned by short scale moisture variability (Veblen et al., 2003; Holz et al., 2009).

The high climatic variability in CCP during the late Holocene has been attributed to the effect of short climatic variability sources such as the Southern Annular Mode (SAM) or El Niño-Southern Oscillation (ENSO) (Markgraf et al., 2007; Haberle and Bennett, 2004; de Porras et al., 2012). Both of them play a role in altering temperatures, precipitation amount and distribution at seasonal to interannual timescales through changes in the strength and latitudinal position of the southern westerlies (Garreaud et al., 2008). In this sense, Holz and Veblen (2009) established the relationship between short-scale climate variability drivers and wildfire activity in rainforests from CCP. Thus, modern wildfire activity in these environments is strongly enhanced by a positive phase of Southern Annular Mode (SAM) associated with a poleward shift in westerly storm tracks and therefore a reduction in precipitation (Garreaud et al., 2009). The positive phase of the Pacific decadal oscillation as well as positive NINO3 (index of ENSO; D'Arrigo et al., 2005) would have also enhanced wildfire occurrence in CCP but only when SAM is on its positive phase (Holz and Veblen, 2009; Holz et al., 2013). Even though paleo-records from CCP show a high variability during the late Holocene, they fail to show environmental and climatic changes in such short scale given their millennial-centennial scale resolution.

Finally, during the last century $(0.1 \mathrm{ka})$, major vegetation changes were recorded at almost all sites in central Chilean Patagonia associated with European settlement (Fig. 6; Martinic, 2005). Forest clearance to widen grazing areas through burning and/or logging such as recorded in Mallín El Embudo or irreversible successional processes in grasslands characterized by the replacement of perennial grasses by shrubs due to overgrazing as inferred from Lago Shaman record (de Porras et al., 2012) were recorded across central Patagonia.

\section{Conclusions}

The Mallín El Embudo pollen and charcoal records demonstrate that vegetation changes at the millennial scale since the Late Glacial are mainly climatically driven, but fire and volcanic disturbances play also a central role in the forest dynamics during the Holocene. Open landscapes dominated by grasses associated with scattered Nothofagus forest patches dominated middle Río Cisnes valley up to $11.2 \mathrm{ka}$ when the development of an open Nothofagus forest related to high fire activity began. At $9.5 \mathrm{ka}$, the presence of a closed forest that experienced a slight canopy opening since $5.7 \mathrm{ka}$ followed by a sudden change around $4.2 \mathrm{ka}$ associated with fire and volcanic disturbances occurred. The recovery of an open Nothofagus forest related to slightly wetter conditions occurred around $2 \mathrm{ka}$ and persisted under highly variable cli- matic conditions up to $0.1 \mathrm{ka}$ when massive forest burning and logging due to European settlement occurred.

The regional integration of terrestrial and marine records allowed light to be shed onto the unclear issues and helped to improve the interpretations concerning the environmental and climatic dynamics of central Chilean Patagonia since the Late Glacial.

In our view, eastern CCP records reflect grass-shrub steppes indicating cold and dry conditions at the Late Glacial. Evergreen forest element values indicate long dispersal transport from western areas such as free-ice continental areas along the Pacific coast. Therefore, lower effective moisture than present is inferred based on terrestrial pollen records from Mallín Pollux, Lago Shaman and Lago Augusta and supported by the pollen and geochemical record from marine core MD07-3088.

On the other hand, late Holocene environmental dynamics seem to be mainly climatically driven, but disturbances such as volcanic activity, fire, and humans (as ignition agents) emerge as crucial to complete the picture. However, high pollen resolution (at centennial, decadal, annual scales) records from appropriately located sites in eastern central Chilean Patagonia are needed to better address the magnitude, direction and timing of vegetation changes due to the different drivers. Besides, late Holocene fire asynchronies across CCP should be carefully analyzed alongside the archaeological record given that the "random" fire patterns could be more closely related to human behavior than to the variable relationships between climate, vegetation and fire.

Acknowledgements. This research was supported by FONDECYT grant no. 1130128. We thank NSF Arizona AMS Facility, University of Arizona for support in some ${ }^{14} \mathrm{C}$ dates; Andrés Zamora and Jean Pierre François for helping with Fig. 1; Charles Stern for preliminary analysis of tephras and Vera Markgraf for providing pollen and charcoal data from Mallín Pollux. We are grateful to Estancia Río Cisnes for logistic support and to Hospital Público San Juan de Dios de La Serena for facilities to take digital $\mathrm{X}$-radiographs. We thank Cathy Whitlock and an anonymous reviewer whose commentaries and suggestions helped to improve the final version of the paper.

Edited by: A.-L. Daniau

\section{References}

Abarzúa, A. M., Villagrán, C., and Moreno, P. I.: Deglacial and postglacial climate history in east-central Isla Grande de Chiloé, southern Chile (43 S), Quaternary Res., 62, 49-59, 2004.

Begtsson, L. and Enell, M.: Chemical Analysis, John Wiley \& Sons Ltd, 451 pp., 1986.

Bennett, K. D., Haberle, S. G., and Lumley, S. H.: The Last GlacialHolocene Transition in Southern Chile, Science, 290, 325-328, 2000.

Caldenius, C.: Las glaciaciones cuaternarias en la Patagonia y Tierra del Fuego, Geograf. Annal., 1-164, 1932. 
del Moral, R. and Grishin, S. Y.: The consequences of volcanic eruptions, in: Ecosystems of Disturbed Ground, edited by: Walker, L. R., Elsevier Science, Amsterdam, 137-160, 1999.

de Porras, M. E., Maldonado, A., Abarzúa, A. M., Cárdenas, M. L., Francois, J. P., Martel-Cea, A., Stern, C. R., Méndez, C., and Reyes, O.: Postglacial vegetation, fire and climate dynamics at Central Chilean Patagonia (Lake Shaman, $44^{\circ} \mathrm{S}$ ), Quaternary Sci. Rev., 50, 71-85, 2012.

Douglass, D. C., Singer, B. S., Kaplan, M. R., Mickelson, D. M., and Caffee, M. W.: Cosmogenic nuclide surface exposure dating of boulders on last-glacial and late-glacial moraines, Lago Buenos Aires, Argentina: interpretive strategies and paleoclimate implications, Quaternary Geochronol., 1, 43-58, 2006.

Enache, M. D. and Cumming, B. F.: Tracking recorded fires using charcoal morphology from the sedimentary sequence of Prosser Lake, British Columbia (Canada), Quaternary Res., 65, 282-292, 2006.

Faegri, K. and Iversen, J.: Textbook of Pollen Analysis, 4th Edn., Blackwell Scientific Publication, 1-327 pp., 1989.

Fletcher, M.-S. and Moreno, P. I.: Have the Southern Westerlies changed in a zonally symmetric manner over the last 14,000 years? A hemisphere-wide take on a controversial problem, Quaternary Int., 253, 32-46, 2012.

Foster, D. R., Knight, D. H., and Franklin, J. F.: Landscape patterns and legacies resulting from Large, infrequent forest disturbances, Ecosystems, 1, 497-510, 1998.

Garreaud, R. D., Vuille, M., Compagnucci, R., and Marengo, J.: Present-day South America climate, Palaeogeogr. Palaeocl., 281, 180-195, 2008.

Garreaud, R. D., Vuille, M., Compagnucci, R., and Marengo, J.: Present-day South America climate, Palaeogeogr. Palaeocl., 281, 180-195, 2009.

Garreaud, R., Lopez, P., Minvielle, M., and Rojas, M.: Large-Scale Control on the Patagonian Climate, J. Climate, 26, 215-230, 2013.

Glasser, N. F., Jansson, K. N., Harrison, S., and Kleman, J.: The glacial geomorphology and Pleistocene history of South America between $38^{\circ} \mathrm{S}$ and $56^{\circ} \mathrm{S}$, Quaternary Sci. Rev., 27, 365-390, 2008.

Glasser, N. F., Harrison, S., Schnabel, C., Fabel, D., and Jansson, K. N.: Younger Dryas and early Holocene age glacier advances in Patagonia, Quaternary Sci. Rev., 58, 7-17, 2012.

Grimm, E.: CONISS: A fortran 77 program for stratigraphically constrained cluster analysis by the method of incremental sum of squares, Comput. Geosci., 13, 13-35, 1987.

Grimm, E.: Tilia 1.7.16 Program, Illinois State Museum, Research \& Collections Center, Springfield, USA, 2012.

Haberle, S. G. and Bennett, K. D.: Modern pollen rain and lake mud-water interface geochemistry along environmental gradients in southern Chile, Rev. Palaeobot. Palynol., 117, 93-107, 2001.

Haberle, S. G. and Bennett, K. D.: Postglacial formation and dynamics of North Patagonian Rainforest in the Chonos Archipelago, Southern Chile, Quaternary Sci. Rev., 23, 24332452, 2004.

Heiri, O., Lotter, A. F., and Lemcke, G.: Loss on ignition as a method for estimating organic and carbonate content in sediments: reproducibility and comparability of results, J. Paleolimnol., 25, 101-110, 2001.
Higuera, P. E., Peters, M. E., Brubaker, L. B., and Gavin, D. G.: Understanding the origin and analysis of sediment-charcoal records with a simulation model, Quaternary Sci. Rev., 26, 1790-1809, 2007.

Higuera, P. E., Brubaker, L. B., Anderson, P. M., Hu, F. S., and Brown, T. A.: Vegetation mediated the impacts of postglacial climate change on fire regimes in the south-central Brooks Range, Alaska, Ecol. Monogr., 79, 201-219, 2009.

Higuera, P. E., Gavin, D. G., Bartlein, P. J., and Hallett, D. J.: Peak detection in sediment-charcoal records: impacts of alternative data analysis methods on fire-history interpretations, Int. J. Wildland Fire, 19, 996-1014, doi:10.1071/WF09134, 2010.

Holz, A. and Veblen, T. T.: Wildfire activity in rainforests in western Patagonia linked to the Southern Annular Mode, Int. J. Wildland Fire, 21, 114-126, 2009.

Holz, A., Haberle, S., Veblen, T. T., De Pol-Holz, R., and Southon, J.: Fire history in western Patagonia from paired treering fire-scar and charcoal records, Clim. Past, 8, 451-466, doi:10.5194/cp-8-451-2012, 2012.

Holz, A., Kitzberger, T., Paritsis, J., and Veblen, T. T.: Ecological and climatic controls of modern wildfire activity patterns across sothwestern South America, Ecosphere, 3, 1-25, 2013.

Kitzberger, T., Raffaele, E., and Veblen, T.: Variable community responses to herbivory in fire-altered landscapes of northern Patagonia, Argentina, Afr. J. Range Forage Sci., 22, 85-91, 2005.

Liu, J., Schmidt, G. A., Martinson, D., Rind, D. H., Russell, G. L., and Yuan, X.: Sensitivity of sea ice to physical parameterizations in the GISS global climate model, J. Geophys. Res., 108, 3053, doi:10.1029/2001JC001167, 2003.

Long, C. J., Whitlock, C., Bartlein, P. J., and Millspaugh, S. H.: A 9000-year fire history from the Oregon Coast Range, based on a high-resolution charcoal study, Can. J. Forest Res.-Revue Canadienne De Recherche Forestiere, 28, 774-787, doi:10.1139/cjfr28-5-774, 1998.

Luebert, F. and Pliscoff, P.: Sinopsis bioclimática y vegetacional de Chile, Editorial Universitaria, Santiago, 318 pp., 2006.

Mancini, M. V., de Porras, M. E., and Bamonte, F. P.: Southernmost South America steppes: vegetation and its modern pollenassemblages representation, in: Steppe Ecosystems: Dynamics, Land Use and Conservation, edited by: Germanno, D., NOVA publishers, New York, 141-156, 2012.

Markgraf, V., Dodson, J. R., Kershaw, A. P., McGlone, M. S., and Nicholls, N.: Evolution of late Pleistocene and Holocene climates in the circum-South Pacific land areas, Clim. Dynam., 6, 193-211, 1992.

Markgraf, V., Whitlock, C., and Haberle, S.: Vegetation and fire history during the last $18,000 \mathrm{cal}$ yr B.P. in Southern Patagonia: Mallín Pollux, Coyhaique, Province Aisén (45 41'30” S, $71^{\circ}$ 50’30” W, 640 m elevation), Palaeogeography, Palaeoclimatology, Palaeoecology, 254, 492-507, 2007.

Martinic, M.: De la Trapananda al Aysén: una mirada reflexiva sobre el acontecer de la Región de Aysén desde la prehistoria hasta nuestros días, Pehuén, Santiago, 539 pp., 2005.

McCormac, F. G., Hogg, A. G., Blackwell, P. G., Buck, C. E., Higham, T. F. G., and Reimer, P. J.: SHCal04 Southern Hemisphere Calibration 0-1000 cal BP., Radiocarbon, 46, 1087-1092, 2004.

McCulloch, R. D., Bentley, M. J., Purves, R. S., Hulton, N. R. J., Sugden, D. E., and Clapperton, C. M.: Climatic inferences from 
glacial and palaeoecological evidence at the last glacial termination, southern South America, J. Quaternary Sci., 15, 409-417, 2000.

Mena, F. and Stafford, T.: Contexto estratigráfico y fechación directa de esqueletos humanos del Holoceno Temprano en Cueva Baño Nuevo 1 (Patagonia Central, Chile), in: Segundo Simposio Internacional del Hombre Temprano en América, edited by: Jiménez, J., González, S., Pompa, J., andOrtiz, F., Instituto Nacional Antropología e Historia, Ciudad de México, 139-154, 2006.

Méndez, C.: Terminal Pleistocene/early Holocene 14C dates from archaeological sites in Chile: discussing critical chronological issues for the initial peopling of the region, Quaternary Int., 301, 60-73, 2013.

Méndez, C. and Reyes, O.: Late Holocene human occupation of Patagonian forests: a case study at Cisnes River basin $\left(44^{\circ} \mathrm{S}\right.$, Chile), Antiquity, 82, 560-570, 2008.

Méndez, C., Reyes, O., Nuevo Delaunay, A., Trejo, V., Barberena, R., and Velásquez, H.: Ocupaciones humanas en la margen occidental de Patagonia Central: eventos de poblamiento en Alto Río Cisnes, Magallania, 39, 223-224, 2011.

Méndez, C., Barberena, R., Reyes, O., and Nuevo Delaunay, A., Isotopic Ecology and Human Diets in the Forest-Steppe Ecotone, Aisén Region, Central-Western Patagonia, Chile, Int. J. Osteoarchaeol., 24, 187-201, doi:10.1002/oa.2337, 2014.

Montade, V., Combourieu Nebout, N., Kissel, C., Haberle, S. G., Siani, G., and Michel, E.: Vegetation and climate changes during the last 22,000yr from a marine core near Taitao Peninsula, southern Chile, Palaeogeogr. Palaeocl., 369, 335-348, 2013.

Moreno, P. I.: Millennial-scale climate variability in northwest Patagonia over the last 15000 yr, J. Quaternary Sci., 19, 35-47, 2004.

Moreno, P. I. and León, A. L.: Abrupt vegetation changes during the last glacial to Holocene transition in mid-latitude South America, J. Quaternary Sci., 18, 787-800, 2003.

Moreno, P. I., Lowell, T. V., Jacobson Jr, G. L., and Denton, G. H.: Abrupt vegetation and climate changes during the Last Glacial Maximum and Last Termination in the chilean Lake District: a case study from Canal de la Puntilla ( $\left.41^{\circ} \mathrm{S}\right)$, Geogr. Annal., 81, 285-311, 1999.

Moreno, P. I., Francois, J. P., Moy, C. M., and Villa-Martinez, R.: Covariability of the Southern Westerlies and atmospheric CO2 during the Holocene, Geology, 38, 727-730, doi:10.1130/g30962.1, 2010a.

Moreno, P. I., Kitzberger, T., Iglesias, V., and Holz, A.: Paleofires in southern South America since the Last Glacial Maximum, Pages news, 18, 75-77, 2010b.

Moy, C. M., Moreno, P. I., Dunbar, R. B., Kaplan, M. R., Francois, J. P., Villalba, R., and Haberzettl, T.: Climate Change in Southern South America During the Last Two Millennia, in: Past Climate Variability in South America and Surrounding Regions, Developments in Paleoenvironmental Research 14, edited by: Vimeux, F., Sylvestre, F., and Khodri, M., Springer, 353-393, 2009.

Naranjo, J. A. and Stern, C. R.: Holocene explosive activity of Hudson volcano, southern Andes, Bull. Volcanol., 59, 291-306, 1998.

Power, M., Marlon, J., Ortiz, N., Bartlein, P., Harrison, S., Mayle, F., Ballouche, A., Bradshaw, R., Carcaillet, C., Cordova, C., Mooney, S., Moreno, P., Prentice, I., Thonicke, K., Tinner, W.,
Whitlock, C., Zhang, Y., Zhao, Y., Ali, A., Anderson, R., Beer, R., Behling, H., Briles, C., Brown, K., Brunelle, A., Bush, M., Camill, P., Chu, G., Clark, J., Colombaroli, D., Connor, S., Daniau, A., Daniels, M., Dodson, J., Doughty, E., Edwards, M., Finsinger, W., Foster, D., Frechette, J., Gaillard, M., Gavin, D., Gobet, E., Haberle, S., Hallett, D., Higuera, P., Hope, G., Horn, S., Inoue, J., Kaltenrieder, P., Kennedy, L., Kong, Z., Larsen, C., Long, C., Lynch, J., Lynch, E., McGlone, M., Meeks, S., Mensing, S., Meyer, G., Minckley, T., Mohr, J., Nelson, D., New, J., Newnham, R., Noti, R., Oswald, W., Pierce, J., Richard, P., Rowe, C., Goni, M., Shuman, B., Takahara, H., Toney, J., Turney, C., Urrego-Sanchez, D., Umbanhowar, C., Vandergoes, M., Vanniere, B., Vescovi, E., Walsh, M., Wang, X., Williams, N., Wilmshurst, J., and Zhang, J.: Changes in fire regimes since the Last Glacial Maximum: an assessment based on a global synthesis and analysis of charcoal data, Clim. Dynam., 30, 887-907, 2008.

Prates, L., Politis, G., and Steele, J.: Radiocarbon chronology of the early human occupation of Argentina, Quaternary Int., 301, 104-122, 2013.

Quensel, P. D.: On the influence of the ice age on the continental watershed of Patagonia, in: Bulletin of the Geological Institution of the University of Upsala, Upsala, 61-92, 1910.

Reimer, P. J., Baillie, M. G. L., Bard, E., Bayliss, A., Beck, J. W., Bertrand, C., Blackwell, P. G., Buck, C. E., Burr, G., Cutler, K B., Damon, P. E., Edwars, R. L., Fairbanks, R. G., Friedrich, M., Guilderson, T. P., Hughen, K. A., Kromer, B., McCormac, F. G., Manning, S., Bronk Ramsey, C., Reimer, R. W., Remmele, S., Southon, J. R., Stuiver, M., Talamo, S., Taylor, F. W., van der Plicht, J., and Weyhenmeyer, C. E.: IntCal04 Terrestrial Radiocarbon Age Calibration, 0-26 Cal Kyr BP, Radiocarbon, 46, 1029-1058, 2004

Reyes, O., Mendez, C., Maldonado, A., Velasquez, H., Trejo, V., Cardenas, M., and Abarzua, A. M.: Uso del espacio de cazadores recolectores y paleoambiente Holoceno en el valle del Río Cisnes, región de Aisén, Chile, Magallania, 37, 91-107, 2009.

Rojas, M. and Moreno, P.: Atmospheric circulation changes and neoglacial conditions in the Southern Hemisphere mid-latitudes: insights from PMIP2 simulations at 6 kyr, Clim. Dynam., 37 , 357-375, 2009.

Rojas, M., Moreno, P., Kageyama, M., Crucifix, M., Hewitt, C., Abe-Ouchi, A., Ohgaito, R., Brady, E., and Hope, P.: The Southern Westerlies during the last glacial maximum in PMIP2 simulations, Clim. Dynam., 32, 525-548, 2009.

Siani, G., Colin, C., Michel, E., Carel, M., Richter, T., Kissel, C., and Dewilde, F.: Late Glacial to Holocene terrigenous sediment record in the Northern Patagonian margin: Paleoclimate implications, Palaeogeogr. Palaeocl., 297, 26-36, 2010.

Steffen, H.: Memoria sobre la expedición exploradora del Río Cisnes (1), in: Viajes de exploración y estudio en la Patagonia Occidental 1892-1902: Anales de la Universidad de Chile, Santiago, 1909.

Stockmarr, J.: Tablets with spores used in absolute pollen analysis, Pollen et Spores, 13, 615-621, 1971.

Stuiver, M., Reimer, P. J., and Reimer, R. W.: CALIB 6.0.1. program, 2005

Szeicz, J. M., Haberle, S. G., and Bennett, K. D.: Dynamics of North Patagonian rainforests from ?ne-resolution pollen, charcoal and 
tree-ring analysis, Chonos Archipelago, Southern Chile, Aust. Ecol., 28, 413-422, 2003.

Tsuyuzaki, S.: Vegetation recovery patterns in early volcanic succession, J. Plant Res., 108, 241-248, 1995.

Umbanhowar, C. E. and Mcgrath, M. J.: Experimental production and analysis of microscopic charcoal from wood, leaves and grasses, The Holocene, 8, 341-346, 1998.

Veblen, T. T., Kitzberger, T., Burns, B. R., and Rebertus, A. J.: Perturbaciones y regeneración en bosques andinos del sur de Chile y Argentina, in: Ecología del Bosque Nativo de Chile, edited by: Armesto, J. J., Villagrán, C., and Arroyo, M. K., Editorial Universitaria, Santiago, 1995.

Veblen, T., Donoso, C., Kitzberger, T., and Rebertus, A.: Ecology of Southern Chilean and Argentinean Nothofagus Forests, in: The Ecology and Biogeography of Nothofagus Forests, edited by: Veblen, T. T., Hill, R. S., and Read, J., Yale University Press, London, 293-353, 1996.

Veblen, T. T., Kitzberger, T., Raffaele, E., and Lorenz, D. C.: Fire history and vegetation changes in northern Patagonia, Argentina, in: Fire and Climatic Changes in Temperate Ecosystems of the Western Americas, edited by: Veblen, T. T., Baker, W., Montenegro, G., and Swetnam, T. W., Springer-Verlag, New York, 2003.

Veblen, T., Kitzberger, T., Raffaele, E., Mermoz, M., González, M. E., Sibold, J. S., and Holz, C. A.: The historical range of variability of fires in the Andean-Patagonian Nothofagus forest region, Int. J. Wildland Fire, 17, 724-741, 2008.
Vidal, O. J. and Reif, A.: Effect of a tourist-ignited wildfire on Nothofagus pumilio forests at Torres del Paine biosphere reserve, Chile (Southern Patagonia), Bosque, 32, 64-76, 2011.

Villagrán, C.: Glacial climates and their effects on the history of the vegetation of Chile; a synthesis based on palynological evidence from Isla de Chiloe, Rev. Palaeobot. Palynol., 65, 17-24, 1990.

Villa-Martinez, R., Moreno, P. I., and Valenzuela, M. A.: Deglacial and postglacial vegetation changes on the eastern slopes of the central Patagonian Andes (47 ${ }^{\circ}$ ), Quaternary Sci. Rev., 32, 8699, 2012.

Whitlock, C. and Larsen, C.: Charcoal as a proxy fire, in: Tracking Environmental Change Using Lake Sediments: Terrestrial, Algal, and Siliceous Indicators, edited by: Smol, J. P., Birks, H. J. B., and Last, W. M., Kluwer Academic Publishers, Dordrecht, The Netherlands, 75-97, 2001.

Whitlock, C., Bianchi, M. M., Bartlein, P. J., Markgraf, V., Marlon, J., Walsh, M., and McCoy, N.: Postglacial vegetation, climate, and fire history along the east side of the Andes (lat $41-42.5^{\circ} \mathrm{S}$ ), Argentina, Quaternary Res., 66, 187-201, 2006.

Whitlock, C., Moreno, P. I., and Bartlein, P.: Climatic controls of Holocene fire patterns in southern South America, Quaternary Res., 68, 28-36, 2007.

Whitlock, C., Higuera, P. E., McWethy, D. B., and Briles, C. E.: Palaeoecological perspectives on fire ecology: revisiting the fireregime concept, The Open Ecol. J., 3, 6-23, 2010. 